\title{
The investigation of luminescence properties of nitride-based heterostructures, containing superlattice
}

\author{
E.A.Menkovich, A.V.Solomonov, S.A.Tarasov, P.A.Yurgin \\ Saint Petersburg Electrotechnical University "LETI", \\ 5 Prof.Popov Str., 197376 St. Petersburg, Russia
}

Received November 11, 2013

\begin{abstract}
The effect of superlattice adding on the luminescence properties of heterostructures based on $(\mathrm{Al}, \mathrm{In}, \mathrm{Ga}) \mathrm{N}$ was investigated. It is shown that using structures with two superlattices: the InGaN/InGaN under active region and the $A I G a N / G a N$ as a top $p$-layer gives the best effect. The elastic stresses on heterointerface of these structure are compensated optimally. As a result they are the most effective and stable functionality.
\end{abstract}

Исследовано влияние введения сверхрешетки (SL) на люминесцентные свойства гетероструктур на основе $(\mathrm{Al}, \mathrm{In}, \mathrm{Ga}) \mathrm{N}$. Показано, что использование структуры с двумя сверхрешетками, InGaN/InGaN под активной областью и $A / G a N / G a N$ в качестве верхнего $p$-слоя, приводит к наилучшему результату. Упругие напряжения на границе раздела в гетеропереходе этих структур компенсируются оптимальным образом. Это приводит к их максимальной әффективности и стабильному функционированию.

Дослідження люмінесцентних властивостей гетероструктур на основі нітриду, що містять надгратку. Е.А.Менькович, А.В.Сололонов, С.А.Тарасов, П.А.Юргін.

Досліджено вплив введення надгратки на люмінесцентні властивості гетероструктур на основі (Al, In, Ga)N. Показано, що використання структури з двома надгратками,

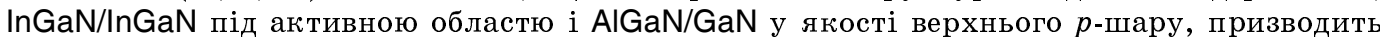
до найкращого результату. Пружні напруги на межі розділу в гетеропереході цих структур компенсуються оптимальним образом. Це призводить до їх максимальної ефективності та стабільного функціонуванню.

\section{Introduction}

One of the important problems of modern science is the development of energy-efficient appliances and devices. Today the solid-state lighting products light-emitting diodes (LEDs) are developed with success. These products have a number of advantages in comparison with traditional. They are less energy intensive, more reliable and cost-effective in use. However, improving the LED luminescence efficiency is actual problems in nowadays.

The LEDs heterostructure which are used in the illumination typically are based on semiconductor solid solutions of nitride (Al,In,Ga)N. It is known that their crystalline structure usually has a lot of defect. This is due to the large lattice mismatch between epitaxial layers and standard substrates on which these epitaxial layers are usually grown. The presence of such lattice mismatch gives rise to elastic strain that can relax to form defects and dislocations during operation of the LED structure. These processes lead to significant changes in luminescence properties of LEDs heterostructures, and deterioration in their performance.

In this paper is proposed to reduce the impact of stress on the elastic properties of luminescence heterostructure based on $(A I, I n, G a) N$ by adding different types of superlattices (SL) in them. 


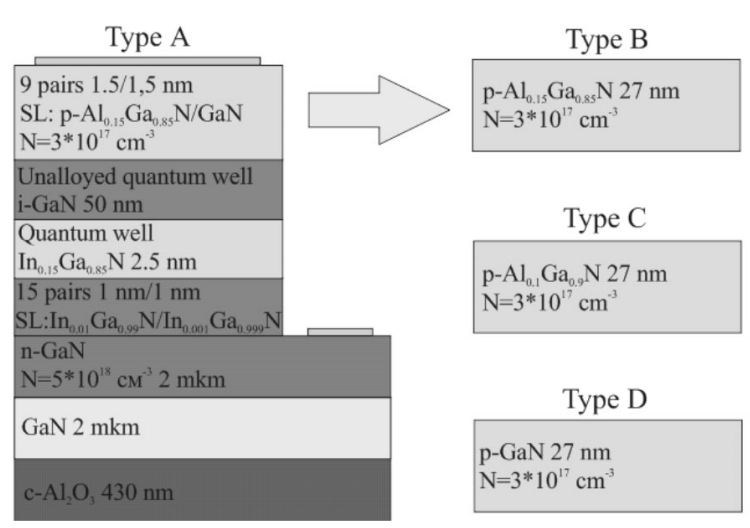

Fig. 1. The structure of the studied samples.

\section{Experimental}

Previously, the authors investigated the effect of the addition of superlattices (In, Ga)N on the luminescence properties in the structures of $(A I, I n, G a) N[1,2]$. In the present paper heterostructures were based on the same solid solutions, some of which included two or one of the SL based on other nitride solid solutions (Fig. 1).

In general, the test samples, except for the last $p-\mathrm{GaN}$ epitaxial layer had a similar sequence of epitaxial layers. The $n-\mathrm{GaN}$ buffer and contact layers were grown on the $c-\mathrm{Al}_{2} \mathrm{O}_{3}$ substrate having $4 \mu \mathrm{m}$ thickness. The SL consisting of $15 \mathrm{In}_{0.01} \mathrm{Ga}_{0.99} \mathrm{~N}$ and $\mathrm{In}_{0.001} \mathrm{Ga}_{0.999} \mathrm{~N}$ layers each having $1 \mathrm{~nm}$ thickness were added before the active region for improvement layer homogeneity.
The active region comprised one $2.5 \mathrm{~nm}$ width $\ln _{0.15} \mathrm{Ga}_{0.85} \mathrm{~N}$ quantum well. Further the low alloyed $50 \mathrm{~nm}$ thickness $i-\mathrm{GaN}$ layer was grown. The final $p-\mathrm{GaN}$ layer was of four types: the first type represented SL comprising 9 pairs of $\mathrm{Al}_{0.15} \mathrm{Ga}_{0.85} \mathrm{~N}$ and $\mathrm{GaN}$ layers of $1.5 \mathrm{~nm}$ thickness (Type 1), the second type - $p$-AIGaN layer with $15 \%$ aluminum fraction (type 2), the third type $p$-AIGaN layer with $10 \%$ aluminum fraction (type 3 ) and the forth type $-p-\mathrm{GaN}$ layer (type 4). The final A1, B2, C3, D4 layers thickness was $27 \mathrm{~nm}$.

The nano-heterostructures study was conducted by means of the author's elaborated diagnosis test system for the investigation nano-heterostructures operating parameters (Fig. 2) [3-6]. The system allows determining all general features of the solid-state emitters and products on its base: spectral, watt- and volt-ampere characteristics, luminescence intensity and efficiency. Moreover, it enables temperature determining of the nano-heterostructures active region. For this purpose a new rapid non-contact method for the active region temperature determining is used [7]. In general, the diagnosis complex provides the most significant optical and electrical characteristics measuring of any LED chip, LED and products on its base within the following ranges: radiation wavelength $200-1100 \mathrm{~nm}$, current $10^{-8}-10 \mathrm{~A}$, voltage $0-250 \mathrm{~V}$, temperature $10-500 \mathrm{~K}$.
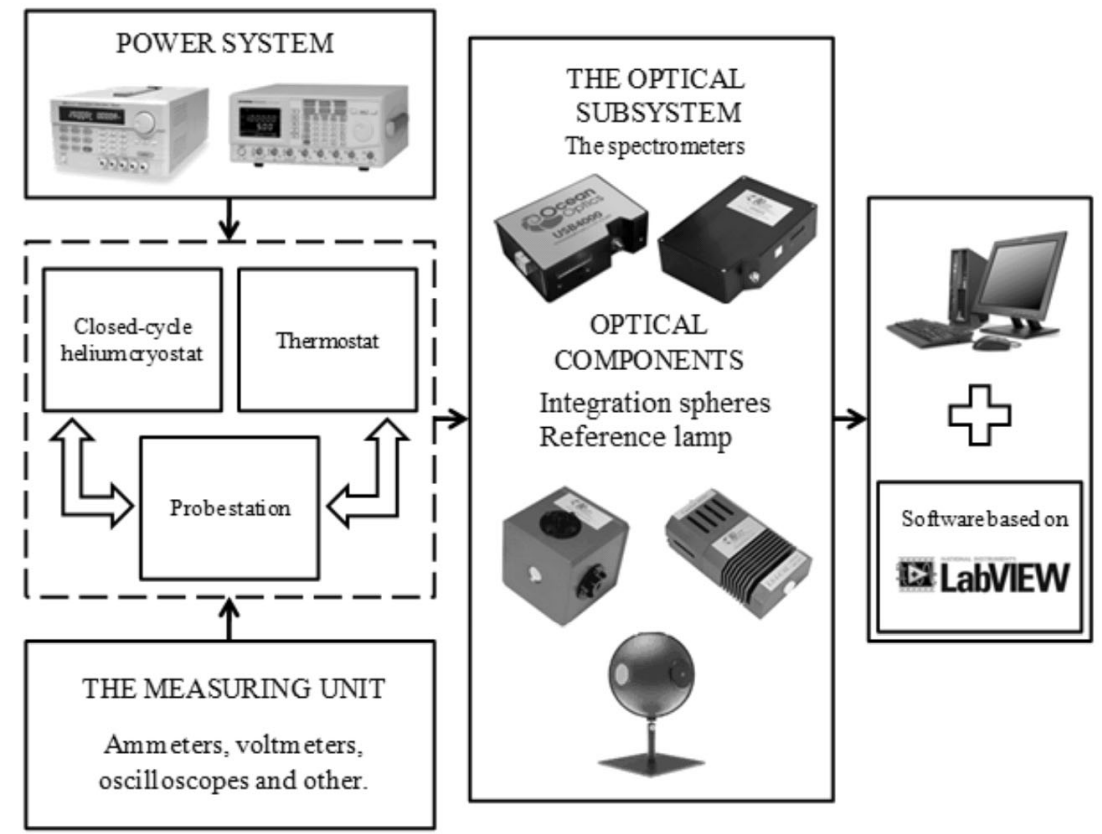

Fig. 2. The test-system for express quality control LEDs. 


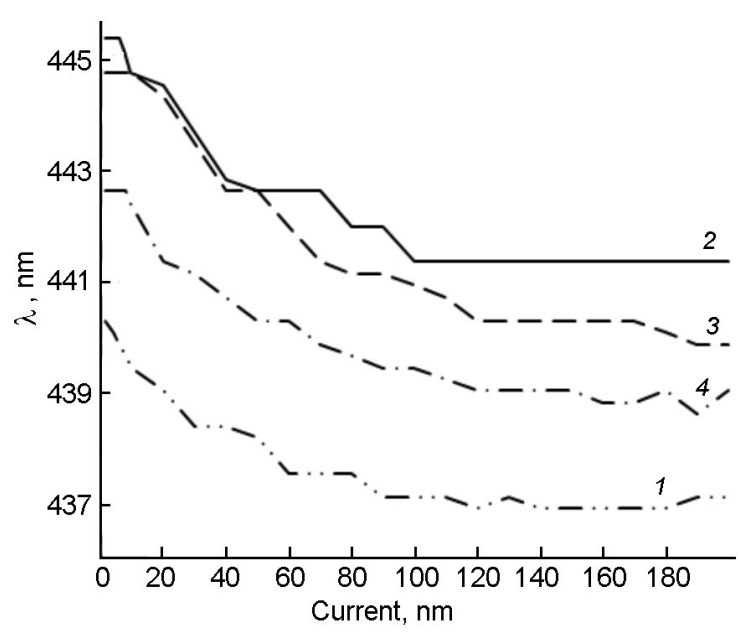

Fig. 3. Wavelength peak dependence on the operating current. Curve 1, 2, 3, 4-type structures.

\section{Results and discussion}

According to $[1,2]$ the structures failing to comprise superlattices under low currents (up to $10 \mathrm{~mA}$ ) demonstrated the significant shift up to $10 \mathrm{~nm}$ spectrum luminescence maximum forward to short-wave region. The authors suggest that the shift of the luminescence spectrum at low currents in these structures due to the influence of elastic stresses that causes the lattice strain at the heterointerface and the built-in electric field. The active region and wells located there are influenced by three main components: $p-n$ junction built-in electric field; built-in field induced by deformations; external field conditioned by an applied voltage. Despite the major impact of the $p-n$ junction on the light-emitting properties of heterostructures, it may not be the main cause of the above effects. The value of this field in the active region structure which contain SL is very close to the voltage values attained in structures without it, since the composition of the emitting layer and the total thickness are similar to each other. However, in a structure with SL the significant shift in luminescence spectrum isn't observed. Very small external voltage drops on the active region of the structure at low operating currents. On their background contribution of the built-field-induced deformations is particularly noticeable. Under his influence the shape of the well is greatly distorted and a quantum-size effect of the Stark is appears [8]. This significantly reduces the distance between the quantum levels. External voltage increasing

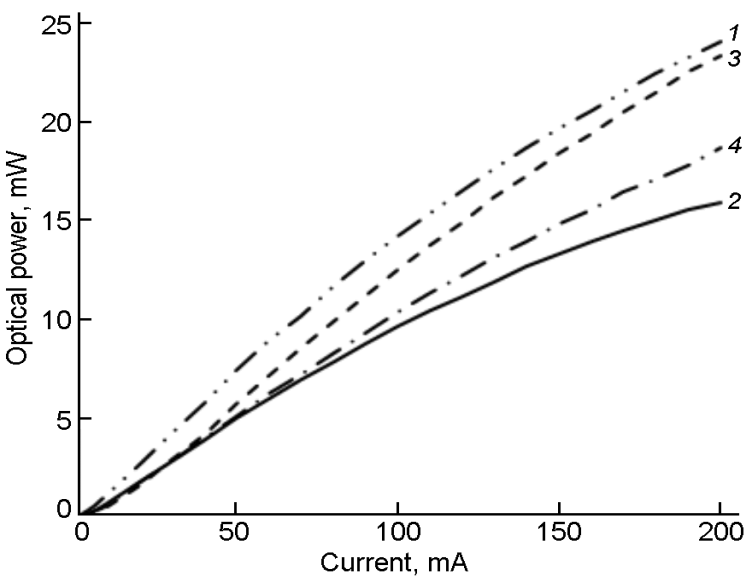

Fig. 4. The optical capacity dependence on the current. Curve 1, 2, 3,4-type structures.

is reduce the impact of built-in field and shift decreases.

SL addition to the nanostructure type 1 allowed to partly compensate elastic stresses thereby the discussed effect was not observed (Fig. 3). Nevertheless, relatively long-wave shift remained as it was and consists about $2.3 \mathrm{~nm}$ in length. Its length equaled $1.8 \mathrm{~nm}$ for the type 2 structures, $4.3 \mathrm{~nm}$ - for the type 3 structures and $3.4 \mathrm{~nm}$ for type 4 structures. This mean incomplete elastic stresses compensation at the single quantum well interface and higher layers lying in the type 1 structure. Probably, the residual elastic stresses within the structure relax without crystal lattice defects formation, therefore it had higher steadiness and operation efficiency. Furthermore, this assumption is confirmed by a lower luminescence efficiency of the type 2 structures where the influence of elastic stresses regarding the wavelength shift is decreased due to the dislocations formations and luminescent efficiency decreasing.

Comparative analysis of $1,2,3,4$ type structures also allowed studying of the final barrier electron intended layer structure influence of the regarding the radiators' luminescent and other operating features (Fig. 4,5).

Considering the achieved optical power and efficiency values the addition of superlattices (type 1) $3.5 \%$ and $2.7 \mathrm{~mW}$, correspondingly, under the current $20 \mathrm{~mA}$ provides the best effect. A more weak effect is provided by the usage of $p-A \mid G a N$ layer with aluminum portion $10 \%$ (type 3 ) (2.4\% and $1.6 \mathrm{~mW}$, correspondingly). Further increasing of $\mathrm{Al}$ concentration makes 


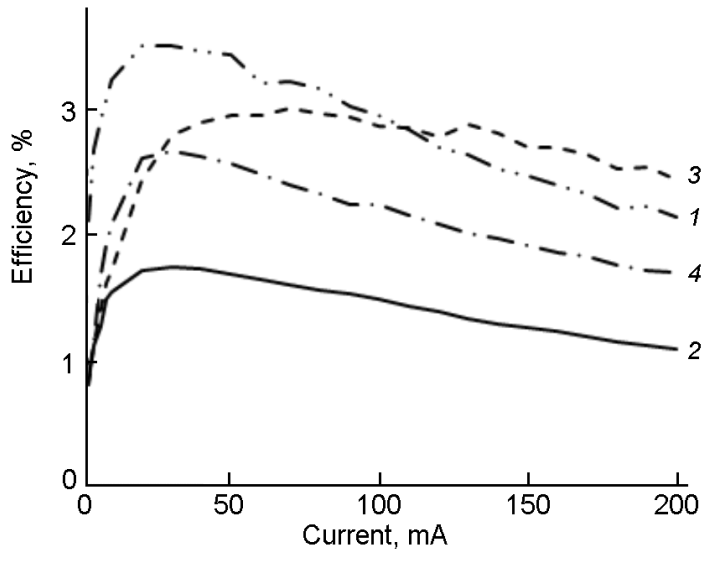

Fig. 5. The dependence of the efficiency on the current. Curve 1, 2, 3, 4 - type structures.

the parameters of obtained samples (type 2) (1.7\% and $1.8 \mathrm{~mW}$, correspondingly) significantly worse. In this case appears that negative influence of the lattice periods mismatch and increased defect formation associated both which exceed the advantages resulting from improved charge carrier confinement. Apparently, in this case, the negative influence of the lattice mismatch and the associated increased defect exceed benefits. This effect strongly proved itself so that optical power of reference type 4 structures with the barrier layer without aluminum be higher than the samples of type $2(2.6 \%$ and $1.7 \mathrm{~mW}$, correspondingly). This effect could be reduced in the superlattice structures due to voltage rearrangement in thin layers consisting in superlattices.

Also it was demonstrated that all studied nanoheterostructures are operable up to the currents exceeding $150 \mathrm{~mA}$. The optical power saturation was not observed in the type $1,3,4$ structures except the type 2 structures which had the lowest efficiency proving their high imperfection. The optical power dependences of the type 1 and type 3 structures coincide while the efficiency is distinguished. The addition of superlattice results in relatively small number of dislocations that doesn't affect the device operation efficiency.

\section{Conclusions}

The structures based on (Al, In, Ga) N were examined. The SL (Al, Ga) N and (In, Ga) $\mathrm{N}$ were contained in these structures, and also had a different structure of top $p$-layer. It was found that the structure with two SL has a high operation stability and best performance. Adding superlattice InGaN/InGaN near the active region in the vicinity of the heterointerface optimally compensate elastic and piezoelectric stress. That compensation reduces the formation of dislocations in these structures. As a result, the luminescence intensity was rised.

\section{References}

1. E.A.Menkovich, S.A.Tarasov, I.A.Lamkin, Functional Materials, 19, 233 (2012).

2. E.A.Menkovich, S.A.Tarasov. I.A.Lamkin et al., J.Phys.:Conf.Ser., 461, 012027 (2013).

3. E.A.Menkovich, S.A.Tarasov. I.A.Lamkin, $I z$ vestiya ETU "LETI", 10, 17 (2012).

4. E.A.Menkovich, S.A.Tarasov. I.A.Lamkin et al., J.Phys.:Conf.Ser., 461, 012028 (2013).

5. S.Kurin, A.Antipov, I.Barash et al., Phys. Status Solidi (c), 10, 289 (2013).

6. A.V.Solomonov, S.A.Tarasov, E.A.Men'kovich et al., Semiconductors, 48, 245 (2014).

7. R.F. Patent No. 2473149 (2013).

8. N.Nanhui, W.Huaibing, L.Jianping et al., $J$. Cryst. Grow., 286, 209 (2006). 